UDC 811.11-112

DOI: $10.17223 / 24109266 / 13 / 4$

\title{
BUILDING A DICTIONARY OF RUSSIAN LEGAL TERMINOLOGY
}

\author{
N.G. Nechipurenko, L.P. Chumakova, E.V. Grishchenko
}

\begin{abstract}
The work presented in this article aims towards a description of the contemporary lexicon of Russian jurisprudence in the 21st century. Legal concepts and terms in the current Russian legal terminology tend to shift within the discursive field, which makes it difficult to systematize legal vocabulary. The lexicon presented in the current study is selected based on the principle of frequency. It is presented as a polylinguistic thesaurus which displays semantics as well as possible use cases in different spheres within the legal field. The terminological system of contemporary Russian law is based in Latin, and this base is still significant for today's complex world of legal education. The work presented in this article gives educators a tool for quickly correcting terminological errors.

Keywords: Russia legal terminology; legal vocabulary; Latin language; lexicography; legal glossaries.
\end{abstract}

\section{Introduction}

The relationship between language and culture in contemporary life is an often debated subject. In the field of jurisprudence, however, language forms the basis for legal competencies. It is the foundation on which systems of law are built. Language is a tool that allows us to define limits within the legal field, identify objects and phenomena in the world around us, create classifications, and pass legal judgments. Contemporary sciences encounter a set of ontological questions related to the problem of formulating new theoretical vocabularies for new methodologies and modes of inquiry. Changes in the world external to language, such as the hyper-informatization and computerization of human life, the impact of media saturation, and the ubiquity of gadgets, all create changes within the language. This includes changes in specialized vocabularies [1].

In this context, the mechanisms of vocabulary formation become interesting to look at. Today, the role of dictionaries in the creation of linguistic personae is growing [2]. Many law schools in Russia today offer Latin only as an elective course, which can have a serious effect on the quality of training that young lawyers receive. A large proportion of legal terms have been in use within legal systems since antiquity, and many legal terms of Latin origin are actively used today. These terms originated in Roman law, which became the basis for the ways in which modern societies structure their legal systems. The needs of contemporary education call for further work on dictionaries that include etymological analysis of vocabulary [3], 
and legal education today needs good resources for describing the structure of legal terminology. The most desired outcome of the process of training specialists in the legal field is to educate people who are able to develop their skills and knowledge independently, creatively overcome professional challenges, and who possess the needed analytical and communication skills [4]. A dictionary of legal terms will allow students to learn and understand vocabulary more quickly and efficiently, which is more and more valuable as information overload increases and available time decreases.

\section{Methods}

The dictionary presented here uses a polylinguistic approach and a comparative methodology, which follows the development of contemporary Russian legal terminology. Descriptive work on the terminology was done through interpretation and generalization of scientific literature, as well as discussions and roundtables with invited scholars, legal specialists, and students [5]. The ordering of entries is alphabetical, with a frequency-based selectivity. The sources drawn upon in this dictionary include the AngloRussian Legal Dictionary [6], The Large Legal Encyclopedic Dictionary [7], a glossary of Roman law terms [8], Veisman's Graeco-Russian Dictionary [9], Dvoretskiy's Latin-Russian Dictionary [10], Dydynskiy's Latin-Russian Glossary for the Sources of Roman law [11], the New Dictionary of Foreign Words [13], and a Dictionary of Legal Terms [14].

\section{Results and discussion}

Each dictionary entry is made up of five columns. The first column is the Russian term. The second contains the Latin (or, less frequently, transliterated Greek) term, and a literal translation of the Latin term into Russian. The third and fourth columns present the term in French and English, and the fifth column contains the definition in Russian. If the definitions of the term in Latin, French, English and Russian are all the same, then the definition is only given once. For example:

\begin{tabular}{|c|l|l|l|l|}
\hline Russian & \multicolumn{1}{|c|}{ Latin } & \multicolumn{1}{c|}{ French } & \multicolumn{1}{c|}{ English } & \multicolumn{1}{c|}{ Definition } \\
\hline $\begin{array}{l}\text { абъюрация } \\
\text { [abjuratsiia] }\end{array}$ & abjuratio & abjuration & abjuration & $\begin{array}{l}\text { Public refutation of } \\
\text { faith or of one's } \\
\text { beliefs }\end{array}$ \\
\hline
\end{tabular}

Synonyms that exist for the term in any of the languages are given after a comma. For example:

\begin{tabular}{|c|l|l|l|l|}
\hline Russian & \multicolumn{1}{c|}{ Latin } & \multicolumn{1}{c|}{ French } & \multicolumn{1}{c|}{ English } & \multicolumn{1}{c|}{ Definition } \\
\hline $\begin{array}{l}\text { алименты } \\
\text { [alimenty] }\end{array}$ & $\begin{array}{l}<\text { alimentum- } \\
\text { upkeep, } \\
\text { patronage }\end{array}$ & $\begin{array}{l}\text { aliments, pension } \\
\text { alimentaire }\end{array}$ & $\begin{array}{l}\text { alimony, } \\
\text { maintenance } \\
\text { that one party is } \\
\text { obliged to pay to } \\
\text { another }\end{array}$ \\
\hline
\end{tabular}


Most of the terms are of Latin origin, but can also be from Greek or another source language. In such cases, the original word is given in the Latin column. For example:

\begin{tabular}{|l|l|l|l|l|}
\hline Russian & \multicolumn{1}{|c|}{ Latin } & \multicolumn{1}{c|}{ French } & English & \multicolumn{1}{c|}{ Definition } \\
\hline $\begin{array}{l}\text { aмнистия } \\
\text { [amnistiia }]\end{array}$ & $\begin{array}{l}<\text { Gr. amnestia - } \\
\text { forgetting, } \\
\text { forgiveness }\end{array}$ & amnestie & amnesty & $\begin{array}{l}\text { Reduction or cancel- } \\
\text { lation of punishment } \\
\text { for a guilty party; } \\
\text { suspension of arrest } \\
\text { warrant; overturning } \\
\text { conviction of some- } \\
\text { one serving a sen- } \\
\text { tence }\end{array}$ \\
\hline $\begin{array}{l}\text { apeнда } \\
\text { [arenda }]\end{array}$ & $\begin{array}{l}\begin{array}{l}\text { Lol. arenda }<\text { late } \\
\text { to rent out }\end{array} \\
\text { bail, location, } \\
\text { fermage } \\
\text { (agriculture })\end{array}$ & lease, rent & $\begin{array}{l}\text { A contract between a } \\
\text { property owner and a } \\
\text { renter, in which the } \\
\text { renter pays a fee for } \\
\text { use of the property }\end{array}$ \\
\hline
\end{tabular}

If the definition in French or English is different from the Russian, then it is given directly following the word. In cases where there are several meanings, they are given in a numbered list. For example:

\begin{tabular}{|c|c|c|c|c|}
\hline Russian & Latin & French & English & Definition \\
\hline $\begin{array}{l}\text { казус } \\
{[\text { kazus }]}\end{array}$ & $\begin{array}{l}\text { casus - event, } \\
\text { fact }\end{array}$ & $\begin{array}{l}\text { cas - case, } \\
\text { circumstance }\end{array}$ & $\begin{array}{l}\text { case - } \\
\text { 1) event; } \\
\text { 2) point of debate in } \\
\text { court; } \\
\text { 3) a court's decision; } \\
\text { legal precedent }\end{array}$ & $\begin{array}{l}\text { 1) event; } \\
\text { 2) an accidental ac- } \\
\text { tion, as opposed to a } \\
\text { premeditated or neg- } \\
\text { ligent one }\end{array}$ \\
\hline
\end{tabular}

If a term has an elaborate set of meanings in contemporary usage [12], these are given in a numbered list. For example:

\begin{tabular}{|c|c|c|c|c|}
\hline Russian & Latin & French & English & Definition \\
\hline $\begin{array}{l}\text { меморандум } \\
\text { [memorandum] }\end{array}$ & $\begin{array}{l}\text { memorandum - } \\
\text { something that } \\
\text { is to be re- } \\
\text { membered }\end{array}$ & memorandum & $\begin{array}{l}\text { memorandum, } \\
\text { memorial }\end{array}$ & $\begin{array}{l}\text { 1) a note for memory } \\
\text { 2) a diplomatic doc- } \\
\text { ument; } \\
\text { 3) a legal opinion }\end{array}$ \\
\hline
\end{tabular}

There are examples of terms that are only used in one language and enter into Russian as a borrowing from that language:

\begin{tabular}{|l|l|l|l|l|}
\hline Russian & Latin & French & English & \multicolumn{1}{c|}{ Definition } \\
\hline $\begin{array}{l}\text { бappистер } \\
\text { [barrister] }\end{array}$ & & & & $\begin{array}{l}\text { A lawyer who has } \\
\text { the right to speak } \\
\text { before the high } \\
\text { courts of Britain, the } \\
\text { USA, Ireland, Cana- } \\
\text { da, and some other } \\
\text { countries }\end{array}$ \\
\hline
\end{tabular}




\begin{tabular}{|l|l|l|l|}
\hline $\begin{array}{l}\text { омбудсмен } \\
\text { [ombudsmen] }\end{array}$ & & $\begin{array}{l}\text { ombudsman - } \\
\text { омбудсмен }\end{array}$ & $\begin{array}{l}\text { Someone with the } \\
\text { authority to investi- } \\
\text { gate complaints }\end{array}$ \\
\hline
\end{tabular}

From a theoretical standpoint, the work on this dictionary is interesting in terms of questions about the systematization of lexical material and patterns that emerge as terminological systems coalesce.

\section{Conclusion}

This dictionary of legal terms helps tell the story of the ways in which the legacy of Roman law entered the Russian legal discourse. Russia's legal language is based on a significant layer of Latin vocabulary. The major pathways by which the Latin terms that make up the foundation of contemporary jurisprudence entered circulation can be traced by applying the polylinguistic approach used in the lexical work done on this dictionary. This approach can reveal the base-level legal concepts and terms which form the linguistic core of contemporary Russian jurisprudence. Shifting legal standards in the Russian legal system are linked to the transmission of legal concepts and their changing definitions as they move between center, periphery, and back. This process disrupts the systematization of the terminological system and leads to the incorrect usage of legal terms. A learner's dictionary of legal terms for contemporary students can help raise the overall level of legal culture and law students' terminological literacy. The work done on this project provides an opportunity for quickly correcting terminological mistakes. It also opens up the linguistic playing field for future lawyers and reveals the systemic links that bring together Russian legal terminology with contemporary international legal language.

\section{Information about the authors:}

Nechipurenko N.G. - Candidat of Philological Sciences, Associate Professor, Social Sciences Department, Novosibirsk Law Institute (branch) of the Federal State Autonomous Educational Institution of Higher Education "National Research Tomsk State University" (Novosibirsk, Russia). E-mail: tribuna@ngs.ru

Chumakova L.P. - Candidat of Law, Associate Professor, Department of Civil Law, Novosibirsk Law Institute (branch) of the Federal State Autonomous Educational Institution of Higher Education "National Research Tomsk State University" (Novosibirsk, Russia). E-mail: info@n-1-i.ru

Grishchenko E.V. - Senior Teacher, Russian language Department, Novosibirsk State Technical University (Novosibirsk, Russia). E-mail: evgrishchenko96@gmail.com.

\section{References}

1. Galkina, S.F., Grishchenko E.V.: Teaching Latin in Medical Schools: Methods, Traditions, Innovations // Advances in Social Science, Education and Humanities Research 2019. Vol. 333: Humanities and Social Sciences: Novations, Problems, Prospects HSSNPP 212-215 (2019) 
2. Chernova, V.D.: Contemporary lexicography as an instrument for forming a linguistically competent persona. URL: https://cyberleninka.ru/article/n/sovremennaya-leksikografiyakak-instrument-formirovaniya-lingvisticheski-kompetentnoy-lichnosti

3. Novodranova, V.F.: Nominative word formation in the Latin language and its reflection in terminology / Laterculi vocum Latinarum et terminorum. M: Jazyki slavyanskikh kul'tur (2008)

4. Nechipurenko, N.G., Chumakova, L.P: On the term fideicommissum // Kognitivnye issledovaniya jazyka. M.: In-t jazykoznaniya RAN; Tambov: Izd.dom TGU im. G.R.Derzhavina 408-412 (2015)

5. Nechipurenko, N.G., Chumakova, L.P.: The Latin language and contemporary law // Metodicheskie i lingvisticheskie aspekty greko-latinskoy meditsinskoy terminologii: materialy konferentsii Vserossiyskoy nauchno-uchebno-metodicheskoy konferentsii. 158160

6. Andrianov, S.N., Berson, A.S., Nikiforov, A.S.: English-Russian Legal Dictionary. M: Rus. jaz. (1993)

7. Barikhin, A.B.: Large Legal Encyclopedic Dictionary. 2nd Ed., revised and expanded. M.: Knizhniy mir (2007)

8. Bartoshek, M.: Roman law: concepts, terms, definitions: translated from Czech] M.: Yurid.lit. (1989)

9. Veysman, A.D.: Greek-Russian dictionary. M.: Greko-latinskiy kabinet Yu.A. Shichalina (1991)

10. Dvoretskiy, I.Kh.: Latin-Russian dictionary: 4th ed. M.: Rus. jaz. (1996)

11. Dydynskiy, F.M.: Latin-Russian Glossary for the Sources of Roman law. M.: Spark (1998)

12. Nechipurenko, N.G., Chumakova, L.P.: The term memorandum in its linguadidactic aspect // Jazyk i kul'tura: sb. statey XXVIII mezhdunarodnoy nauchnoy konferentsii. Tomsk: Izd. Dom Tomsk. gos. Un-ta, 67-71 (2018)

13. New dictionary of foreign words. Minsk: Sovremenniy literator (2008)

14. Dictionary of legal terms / compiled by E.V. Grishchenko. Novosibirsk: Izd-vo SGUPSa (2008) 